\title{
Early Events of Human T Lymphocyte Activation Are Associated with Type I Protein Kinase A Activity
}

Dama Laxminarayana, Abdelkrim Berrada, and Gary M. Kammer

Department of Medicine, Case Western Reserve University School of Medicine, Cleveland, Ohio 44106; and Department of Internal Medicine, The Bowman Gray School of Medicine of Wake Forest University, Winston-Salem, North Carolina 27157

\begin{abstract}
Human T lymphocytes possess both the type I and II isozymes of protein kinase A (PKA). The type I (PKA-I) isozyme is predominantly associated with the plasma membrane, whereas the type II (PKA-II) isozyme is primarily localized to the cytosol. Because the functions of both PKA-I and PKA-II isozymes in the biochemical events of $T$ lymphocyte activation have not been clearly elucidated, we tested the hypothesis that very early events of normal human $T$ lymphocyte activation are mediated by the PKA-I and/or PKA-II isozyme(s). Fresh normal human $\mathrm{T}$ cells and a normal human $\mathrm{CD4}^{+} \mathrm{T}$ cell line (GK606) activated with anti-CD3- $\epsilon$ and recombinant interleukin $1 \alpha$ (rIL-1 $\alpha$ ) exhibited a peak six- to sevenfold increase of PKA phosphotransferase activity at 5 min that returned to baseline by $60 \mathrm{~min}$. Similarly, both fresh $T$ cells and the $T$ cell line activated by phorbol myristate acetate and ionomycin demonstrated a peak eightfold increase of PKA activity by $15 \mathrm{~min}$ that returned toward baseline by $60 \mathrm{~min}$. Chromatographic separation of the PKA isozymes and quantification of phosphotransferase activities after $T$ cell activation by either agonist pair showed preferential activation of the PKA-I isozyme, resulting in a significant reduction in the ratio of PKA-I to PKA-II isozyme activity from 3.1:1-6.2:1 to 1.1:1-3.2:1. PKA-I isozyme activation resulted in the release of free catalytic $(C)$ subunit, an increase in $\mathrm{C}$ subunit phosphotransferase activity, and the phosphorylation of $T$ cell plasma membrane-associated proteins, p14, p17, p20, p21, p38, and p48. However, activation of the PKA-I isozyme did not appear to be required for the transcription of IL-2 mRNA, an event necessary for mitosis. These data indicate that ligand-induced $T$ cell activation is associated with rapid activation of the PKA-I, but not PKA-II, isozyme that results in phosphorylation of plasma membrane-associated proteins. The involvement of the PKA-I isozyme during the very early events of $T$ cell activation suggests that this isozyme may be an antigen- or mitogen-stimulated protein kinase. (J. Clin. Invest. 1993. 92:2207-2214.) Key words: signal transduction • cAMP • protein kinases • lymphocytes • protein phosphorylation
\end{abstract}

Address correspondence to Dr. Gary M. Kammer, Section on Rheumatology, Bowman Gray School of Medicine, Wake Forest University, Medical Center Boulevard, Winston-Salem, NC 27157-1058. 1993.

Received for publication 25 June 1992 and in revised form 21 June

J. Clin. Invest.

(C) The American Society for Clinical Investigation, Inc.

$0021-9738 / 93 / 11 / 2207 / 08 \quad \$ 2.00$

Volume 92, November 1993, 2207-2214

\section{Introduction}

T lymphocyte activation encompasses a complex cascade of biochemical and molecular events resulting in the production of lymphokines, upregulation of receptors, and, ultimately, mitosis. This process entails: $(a)$ apposition of the $\mathrm{T}$ cell to an antigen-presenting accessory cell, $(b)$ presentation of an antigenic peptide bound to a class I or II major histocompatibility molecule to the $T$ cell antigen receptor $(T C R)(1),(c)$ occupancy of the T cell interleukin 1 receptor (IL-1R) by IL-1 (2), $(d)$ a physical interaction between the T lymphocyte and accessory cell (3), and (e) the subsequent actuation of a signal(s) that is conveyed to the nucleus. This biochemical signal(s) triggers the sequential transcription of multiple genes over time, including IL-2 $(4,5)$. The primary phase of T cell activation can be replicated in vitro by substituting monoclonal antiCD3 antibody bound to a surface for antigen (6) in the presence of recombinant IL- $1 \alpha($ rIL- $1 \alpha)$. Within several minutes of occupancy of the TCR/CD3 complex by anti-CD3, two families of protein kinases are activated. Protein kinase $C(P K C)^{1}$ phosphorylates multiple substrates, including the $\gamma$ and $\delta$ chains of $\operatorname{CD} 3(5,7,8)$; tyrosine protein kinases phosphorylate alternative substrates, including the $\zeta$ chain of $\operatorname{CD} 3(9,10)$.

The role of protein kinase A (cAMP-dependent protein kinase, PKA; EC 2.7.1.37) in these early events of human $T$ cell activation remains incompletely defined $(11,12)$. This is not surprising, since the precise functions of the PKA-I and PKAII isozymes in cell growth and differentiation are controversial. The PKA-I isozyme has been correlated with both cell growth and differentiation, depending upon the tissue analyzed (13). Early analyses of lymphocyte mitogenesis stimulated by Concanavalin A found a predominant activation of the PKA-I isozyme after $4 \mathrm{~h}$ in culture (14). More recently, the use of antisense oligonucleotides to alter the expression of the PKA type I regulatory (RI) and RII subunits in the human HL-60 promyelocytic leukemia cell line demonstrated that the $\alpha$ isoform of PKA-I was necessary to drive the cell's neoplastic growth (15). Our demonstration that the PKA-I isozyme is predominantly localized to the plasma membrane of human $T$ lymphocytes (12) suggested that this isozyme could be involved in the process of $\mathrm{T}$ cell activation.

Because a cascade of protein kinases appears to be activated sequentially during the early events of $T$ lymphocyte activation, we tested the hypothesis that very early events of normal human $\mathrm{T}$ lymphocyte activation are mediated by the PKA-I

1. Abbreviations used in this paper: $\mathrm{bt}_{2} \mathrm{CAMP}$, dibutyryl cAMP; $\mathrm{H}-7$, 1-(5-isoquinolinesulfonyl)-2-methylpiperazine; PKA and PKC, protein kinases A and C, respectively; PKA-I and PKA-II, types I and II isozymes of PKA; Rp-cAMPS, the ( Rp) diastereomer of adenosine cyclic 3',5'-phosphorothioate. 
and/or PKA-II isozyme(s). Our results demonstrated that the PKA-I isozyme, but not the PKA-II isozyme, is activated by 1 min, exhibits peak phosphotransferase activity at $5 \mathrm{~min}$, and phosphorylates several plasma membrane-associated proteins. The phosphorylation of membrane proteins by the PKA-I isozyme may be an integral early event in the $T$ cell activation process.

\section{Methods}

Cells. Fresh T lymphocytes were prepared from PBMC of healthy donors as described (16). Cytofluorographic analysis (FACS II; ${ }^{\circledR}$ Becton Dickinson Immunocytometry Systems, San Jose, CA) of enriched T lymphocyte preparations with FITC-anti-CD3- $\epsilon$ (Ortho Diagnostics, Raritan, NJ) demonstrated that $95 \pm 0.9 \%$ possessed the CD3 membrane complex that defines $\mathrm{T}$ lymphocytes. The GK606 T cell line was derived from a healthy donor by culturing PBMC with $10 \mu \mathrm{g} / \mathrm{ml}$ PHA in RPMI 1640 supplemented with $10 \%$ heat-inactivated FCS, $200 \mathrm{mM}$ L-glutamine, $10 \mu \mathrm{g} / \mathrm{ml}$ gentamicin, and $10 \mathrm{mM}$ Hepes for $3 \mathrm{~d}$. T cells $\left(2 \times 10^{5} / \mathrm{ml}\right)$ were then cultured with $10^{4} / \mathrm{ml}$ irradiated, syngeneic PBMC in the same culture medium in the presence of $5 \mathrm{U} / \mathrm{ml} \mathrm{rIL-2}$ (Genzyme, Cambridge, MA). The cells were passed twice weekly. After three passages, the $\mathrm{CD}^{+}{ }^{+} \mathrm{CD}^{+}$and natural killer cell subsets were eliminated by treatment with monoclonal anti-CD8 (Ortho Diagnostics), anti-CD56 (Coulter Electronics Inc., Hialeah, FL), and rabbit complement (Accurate Chemical \& Scientific Corp., Westbury, NY); cytofluorographic analysis demonstrated that the quiescent cell line expressed $>94 \% \mathrm{CD}^{+}, \mathrm{CD}^{+}, \mathrm{CD}^{-}, \mathrm{CD}^{-} 5 \mathrm{RO}^{+}, \mathrm{CD}^{-} 6^{-}$surface phenotype; $<3 \%$ and $1 \%$ were $\mathrm{CD}^{+}, \mathrm{CD}^{+}$and $\mathrm{CD} 56^{+}$, respectively.

Cells were made to enter the $G_{0} / G_{1}$ phase of the cell cycle before activation by culturing for $24 \mathrm{~h}$ in RPMI 1640 supplemented with $2 \%$ FCS. Cytofluorographic analysis using propidium iodide confirmed that $>94 \%$ of $T$ cells had entered the $G_{0} / G_{1}$ phase (17). In the $G_{0} / G_{1}$ phase, the cells did not express either IL-2 mRNA or IL-4 mRNA, but constitutively expressed both IL-2R $\alpha$ mRNA and IL-2R $\beta$ mRNA. Upon activation, this cell line expressed IL-2 mRNA, IL-2R $\alpha$ mRNA, and IL-2R $\beta$ mRNA, but not IL- 4 mRNA.

$T$ lymphocyte activation. Both fresh $\mathrm{T}$ lymphocytes and the $\mathrm{T}$ cell line were activated by two methods. The first technique used anti-CD3$\epsilon$ and rIL- $1 \alpha$ to activate T cells because these agonists most closely reproduce physiologic conditions by binding to surface receptors. Sterile polystyrene culture tubes $(12 \times 75 \mathrm{~mm})$ were coated with $10 \mu \mathrm{g} / \mathrm{ml}$ of affinity-purified goat anti-mouse $\mathrm{IgG}$ at $4^{\circ} \mathrm{C}$ overnight, washed with

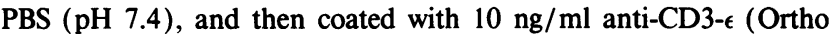
Diagnostics) or anti-CD4 (Ortho Diagnostics) for $2 \mathrm{~h}$ at $4^{\circ} \mathrm{C} .3 \times 10^{6} \mathrm{~T}$ cells were resuspended in RPMI 1640 supplemented with $10 \mathrm{mM}$ Hepes, $200 \mathrm{mM}$ L-glutamine, $10 \% \mathrm{FCS}, 10 \mu \mathrm{g} / \mathrm{ml}$ gentamicin, and 50 $\mathrm{U} / \mathrm{ml} \mathrm{rIL}-1 \alpha$. The cells were gently centrifuged at $500 \mathrm{rpm}$ for $1 \mathrm{~min}$ to enhance attachment of cells to the antibody-coated tubes. In some experiments, PMA was substituted for rIL- $1 \alpha$. The second method of activation used various concentrations of PMA and $0.5 \mu \mathrm{M}$ ionomycin. Cells were maintained at $4^{\circ} \mathrm{C}$ until addition to prewarmed culture medium. After incubation at $37^{\circ} \mathrm{C}$ for varying times, the cells were immediately harvested.

cAMP-inducible, PKA-I isozyme-catalyzed protein phosphorylation. Normal T lymphocyte plasma membrane containing PKA-I isozyme activity was isolated as described (12). cAMP-inducible, PKA-I isozyme-catalyzed phosphorylation of membrane-associated proteins was analyzed by one-dimensional PAGE (1D-PAGE) and autoradiography as described (18).

$P K A$ assay. Quiescent or activated $\mathrm{T}$ lymphocytes were lysed in $600 \mu 1$ of cold lysis buffer (buffer A; $0.25 \mathrm{M}$ sucrose, $5 \mathrm{mM}$ Tris-HCl [pH 7.2], 5 mM EGTA, $1 \mathrm{mM}$ PMSF, $0.1 \mathrm{mM}$ DTT, $0.1 \%$ Triton $\mathrm{X}-100$, and $10 \mu \mathrm{g} / \mathrm{ml}$ each of leupeptin and aprotinin ) at $4^{\circ} \mathrm{C}$ by sonicating twice at $60 \mathrm{~Hz}$ for $15 \mathrm{~s}$. The PKA phosphotransferase activity from cellular homogenates was quantified by a phosphocellulose paper assay that used the synthetic heptapeptide leu-arg-arg-ala-ser-leu-gly (Kemptide; Sigma Chemical Co., St. Louis, MO) as the phosphate acceptor (12). The reaction mixture of $200 \mu \mathrm{l}$ contained $20 \mathrm{mM}$ Tris$\mathrm{HCl}$ (pH 7.4), $10 \mathrm{mM} \mathrm{MgCl}$, $0.5 \mathrm{mM}$ EGTA, $100 \mu \mathrm{M}$ ATP, $50 \mu \mathrm{M}$ $\gamma-\left[{ }^{32} \mathrm{P}\right]$ ATP $(100-200 \mathrm{cpm} / \mathrm{pmol})$, and $20 \mu \mathrm{g}$ of cell homogenate protein.

Because experiments were designed to quantify PKA activity stimulated by endogenous cAMP present in unactivated T cells, after activation of $T$ cells with either agonist pair, or after interaction of $T$ cells with anti-CD4 and rIL-1 $\alpha$, an exogenous source of CAMP was not added to the assay mixture.

The reaction was performed for $5 \mathrm{~min}$ at $30^{\circ} \mathrm{C}$ and stopped by addition of $50 \mu$ of $2.5 \%$ BSA and $0.02 \%$ deoxycholate. Samples were immediately filtered through phosphocellulose paper disks (P81; Whatman Chemical Separation Inc., Clifton, NJ). The disks were washed five times in $75 \mathrm{mM}$ phosphoric acid and dried, and the protein-bound radioactivity was quantified by liquid scintillation spectrometry (model 3255, Packard Instrument Co. Inc. United Technologies, Downers Grove, IL). Specific PKA phosphotransferase activity was determined by subtracting $\mathrm{cpm}$ in the presence of the cyclic nucleotide protein kinase inhibitor, $\mathrm{H}-8$ ( $N$-[2-(methylamino)ethyl] 5isoquinolinesulfonamide [ $\mathrm{K}_{\mathrm{i}}=1.2 \mu \mathrm{M}$; Seikagaku America, St. Petersburg, FL]) (19) from cpm in the absence of $\mathrm{H}-8$, and was expressed as $\mathrm{pmol} / \mathrm{min}$ per $\mathrm{mg}$ protein.

Separation of PKA isozymes by column chromatography. Quiescent or activated $\mathrm{T}$ lymphocytes were lysed in $500 \mu \mathrm{l}$ of cold buffer B ( $10 \mathrm{mM} \mathrm{K}_{2} \mathrm{HPO}_{4}$ [pH 7.2], $1 \mathrm{mM}$ EDTA, and $0.1 \mathrm{mM}$ DTT). Separation of PKA-I and PKA-II isozymes was performed by tandem DE52cellulose and CM-sephadex column chromatography. DE52-cellulose retains the holoenzymes; free $\mathrm{C}$ subunits pass through the DE52-cellulose column and are retained on the CM-sephadex column (20). The DE52-cellulose column (bed volume, $1 \mathrm{ml} ; 0.8 \mathrm{~cm} \times 4.3 \mathrm{~cm}$ ) and $\mathrm{CM}$-sephadex column (bed volume, $2 \mathrm{ml} ; 0.8 \mathrm{~cm} \times 4.3 \mathrm{~cm}$ ) were equilibrated with buffer $\mathbf{B}$.

$1 \mathrm{mg}$ of cellular homogenate was loaded onto the DE52-cellulose column and rinsed with $10 \mathrm{ml}$ of buffer $B$. The column was eluted with a continuous, linear gradient $(0-0.4 \mathrm{M} \mathrm{NaCl})$ established by mixing of $18 \mathrm{ml}$ of buffer B plus $18 \mathrm{ml}$ of buffer B containing $0.4 \mathrm{M} \mathrm{NaCl}$. The flow rate was $0.2 \mathrm{ml} / \mathrm{min}$, and the average duration of elution was $3 \mathrm{~h}$. Fractions $(60 \mu \mathrm{l})$ were assayed for PKA-I- and PKA-II-catalyzed phosphotransferase activity after addition of $10 \mu \mathrm{M}$ cAMP. The addition of exogenous CAMP to the eluted isozyme is necessary in order to dissociate the $R$ subunits from the $C$ subunits, permitting activation of the isozyme and quantification of its phosphotransferase activity. The peak PKA-I isozyme activity eluted at fraction 11 and the peak PKA-II isozyme activity eluted at fraction 23 . Free $C$ subunit was eluted from a CM-sephadex column with buffer B containing $0.55 \mathrm{M} \mathrm{NaCl}$ (20). C subunit phosphotransferase activity was quantified in the absence of cAMP. Total PKA-I and PKA-II phosphotransferase activities and free $C$ subunit activity were obtained by summing the enzyme activities in each fraction for PKA-I, PKA-II, and C subunit and expressing the total activities as $\mathrm{pmol} / \mathrm{min}$.

The areas under the elution curves defining the PKA-I and PKA-II isozymes were quantified by a MOP-Videoplan image analysis system (Kontron-Bildanalyse). The ratio of PKA-I to PKA-II isozyme activity was calculated by dividing the area under the curve of PKA-I activity by the area under the curve of PKA-II activity (12); the mean activity ratio in these experiments was 4.0:1 (range, 3.1:1-6.2:1). A reduction in the ratio of PKA-I to PKA-II activity indicates endogenous cAMP-inducible activation and use of a portion of the PKA-I isozyme.

Protein concentrations. Protein concentrations were quantified by the method of Bradford (21).

Message amplification phenotyping (MAPPing) of IL- 2 and $\beta$-actin $m R N A s$. We used the reverse transcriptase polymerase chain reaction (RT-PCR) to amplify the IL-2 and $\beta$-actin mRNAs. This technique identifies the presence or absence of these mRNAs, but does not quantify the transcripts. 
Total RNA was isolated from $3 \times 10^{6} \mathrm{~T}$ lymphocytes (22) and quantified at OD 260. The RNA was used to synthesize single-stranded cDNA (sscDNA) essentially as described (23). The cDNA mixture was diluted to $50 \mu$ l with TE buffer ( $10 \mathrm{mM}$ Tris- $\mathrm{HCl}$ [pH 8.0], $1 \mathrm{mM}$ EDTA), and $5 \mu \mathrm{L}$ was used in the amplification reaction with oligonucleotide primers specific for IL- 2 and $\beta$-actin gene message.

The IL- 2 and $\beta$-actin primers were obtained from Clontech (Palo Alto, CA). 5' and $3^{\prime}$ primers were complementary to sequences in the first and last exons, respectively. The specificity of the amplified bands in each case was confirmed by their predicted sizes as well as by cloning and sequencing the PCR products. The sequences of the primers are:

\section{IL-2 462 bp 5'-ATGTACAGGATAGCAACTCCTGTCTT}

\section{3'-GTTAGTGTTGAGATGATGCTTTGAC}

$\beta$-actin 1,126 bp 5 -TGACGGGGTCACCCACACTGTGCCCATCTA

\section{3'-CTAGAAGCATTGCGGTGGACGATGG-}

\section{AGGG.}

Each reaction mixture consisted of $5 \mu$ l of sscDNA, 25 pmol of each primer, $5 \mu \mathrm{l}$ of $10 \times$ Taq buffer, $8 \mu \mathrm{l}$ of dNTP mix, $1.25 \mathrm{U}$ of Taq polymerase, and nuclease-free water to a final volume of $50 \mu \mathrm{l}$. Taq buffer, dNTP mix, and Taq polymerase were obtained from PerkinElmer Cetus (Emeryville, CA). The reaction mixtures were subjected to 30 cycles of denaturation $\left(94^{\circ} \mathrm{C}, 1 \mathrm{~min}\right)$, annealing for $2 \mathrm{~min}$ at $60^{\circ} \mathrm{C}$, and extension for $3 \mathrm{~min}$ at $72^{\circ} \mathrm{C}$ with a final extension of $5 \mathrm{~min}$ at $72^{\circ} \mathrm{C}(24)$ using a DNA thermal cycler (Perkin-Elmer Cetus). $5 \mu \mathrm{l}$ of reaction mixture was then analyzed on a $2 \%$ agarose gel in Tris- $\mathrm{HCl}$ / acetate/EDTA (TAE) buffer. $1 \mu \mathrm{g}$ of HaelII-digested $\phi \times 174$ DNA (GIBCO BRL, Gaithersburg, MD) was used as molecular weight markers: 1,353, 1,078, 872, 603, 310, and 234 bp.

Statistics. Statistical significance $(P \leq 0.05)$ was calculated by the paired $t$ test or nonparametric Mann-Whitney $U$ test using Sigma Stat (Jandel Scientific, Corte Madera, CA).

\section{Results}

Anti-CD3- $\epsilon$ and $r I L-1 \alpha$ stimulates $P K A$ phosphotransferase activity. Fresh human T cells or the quiescent, IL-2-dependent T cell line (GK606) were activated with the agonist pair, $10 \mathrm{ng} /$ $\mathrm{ml}$ anti-CD3- $\epsilon$ and $50 \mathrm{U} / \mathrm{ml} \mathrm{rIL-} 1 \alpha$, for intervals to $60 \mathrm{~min}$. When this agonist pair was used, both fresh $\mathrm{T}$ lymphocytes and the GK606 line transcribed IL-2 mRNA (Fig. 1, lane 3, cell line). The demonstration of transcription of IL-2 mRNA (5) confirmed that this agonist pair effectively activates both normal $T$ cells and the quiescent GK606 cell line.

To establish whether or not PKA phosphotransferase activity occurs during the very early phase of $T$ cell activation, we quantified PKA activity in T cells activated with anti-CD3- $\epsilon$ and rIL- $1 \alpha$ over $60 \mathrm{~min}$. Activated fresh T cells exhibited PKA activity at $1 \mathrm{~min}$; the PKA phosphotransferase activity peaked 6.4 -fold ( $245 \mathrm{pmol} / \mathrm{min}$ per $\mathrm{mg}$ protein $)$ by $5 \mathrm{~min}$ and returned toward baseline (baseline, $38 \mathrm{pmol} / \mathrm{min}$ per $\mathrm{mg}$ ) by 60 min (Fig. 2). Increasing concentrations of anti-CD3- $\epsilon$ (from 1 to $250 \mathrm{ng} / \mathrm{ml}$ ) or rIL- $1 \alpha$ (from 5 to $500 \mathrm{U} / \mathrm{ml}$ ) did not further increase PKA activity. Similarly, activation of the quiescent GK606 line with anti-CD3- $\epsilon$ and rIL- $1 \alpha$ activated PKA at 1 min, which peaked 6.9 -fold ( $195 \mathrm{pmol} / \mathrm{min}$ per $\mathrm{mg}$ ) over baseline $(28 \mathrm{pmol} / \mathrm{min}$ per $\mathrm{mg})$ at $5 \mathrm{~min}$ and returned toward baseline ( $67 \mathrm{pmol} / \mathrm{min}$ per $\mathrm{mg}$ ) by $60 \mathrm{~min}$. Substitution of anti-CD4 for anti-CD3- $\epsilon$ failed to activate PKA (Fig. 2). Finally, neither $10 \mathrm{ng} / \mathrm{ml}$ anti-CD3- $\epsilon$ nor $50-250 \mathrm{U} / \mathrm{ml}$ rIL- $\alpha$
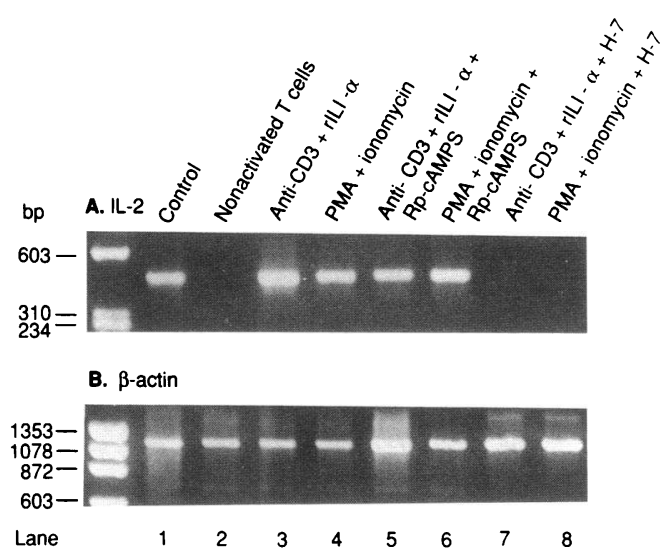

Figure 1. Expression of IL-2 mRNA and $\beta$-actin mRNA in the GK606 T cell line activated by anti-CD3- $\epsilon$ and rIL- $1 \alpha$ or PMA and ionomycin in the absence or presence of inhibitors of PKA and PKC. $(A) \mathrm{T}$ cells were cultured in medium in the absence of either ligand pair (lane 2). Activation of T cells by $10 \mathrm{ng} / \mathrm{ml}$ anti-CD3- $\epsilon$ and 50 $\mathrm{U} / \mathrm{ml}$ rIL- $1 \alpha$ or $10 \mathrm{ng} / \mathrm{ml} \mathrm{PMA}$ and $0.5 \mu \mathrm{M}$ ionomycin led to optimal expression of IL-2 mRNA (lanes 3 and 4 ) at 12-16 h. T cells were pretreated with $250 \mu \mathrm{M} \mathrm{Rp}$-cAMPS (lanes 5 and 6 ) or $100 \mu \mathrm{M} \mathrm{H}-7$ (lanes 7 and 8 ) for $10 \mathrm{~min}$ at $37^{\circ} \mathrm{C}$, and subsequently activated with either ligand pair. $(B) \beta$-actin mRNA expression in cells treated as above. The data are representative of five independent experiments using the GK606 cell line.

alone activated PKA in fresh T cells or the GK606 line over 60 min (data not shown).

Treatment of either fresh $\mathrm{T}$ cells or the quiescent $\mathrm{T}$ cell line with the agonist pair, PMA and ionomycin, also induced IL-2 mRNA expression (Fig. 2, lane 4). To determine whether this agonist pair concomitantly activated PKA, fresh $\mathrm{T}$ cells were treated with $10 \mathrm{ng} / \mathrm{ml}$ PMA and $0.5 \mu \mathrm{M}$ ionomycin for intervals to $60 \mathrm{~min}$. PKA activity was detected at $1 \mathrm{~min}$, peaked

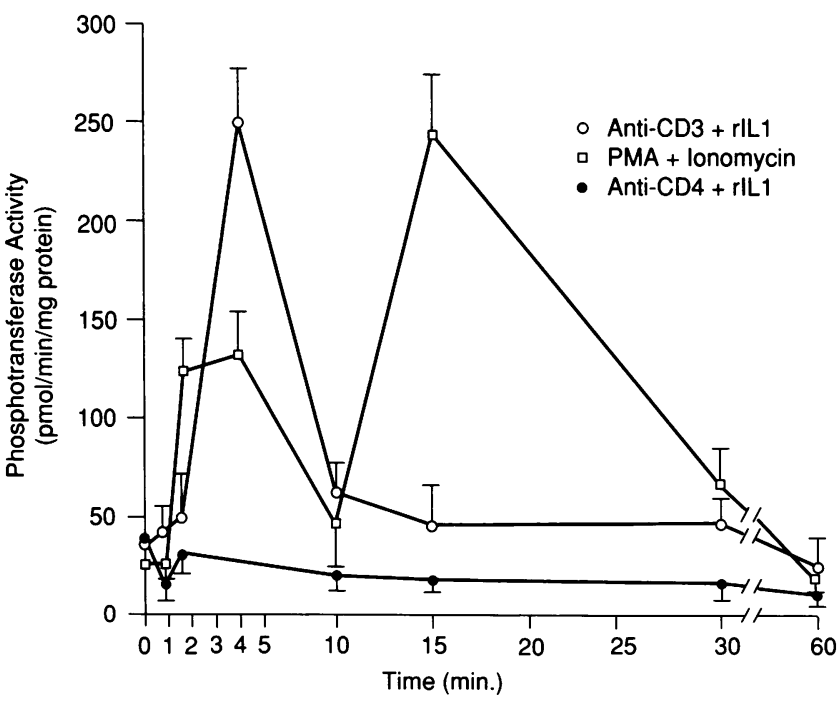

Figure 2. Time-dependent activation of total PKA phosphotransferase activity in fresh human $T$ lymphocytes treated with $10 \mathrm{ng} / \mathrm{ml}$ anti-CD3- $\epsilon$ and $50 \mathrm{U} / \mathrm{ml} \mathrm{rIL}-1 \alpha(\mathrm{O}), 10 \mathrm{ng} / \mathrm{ml}$ PMA and $0.5 \mu \mathrm{M}$ ionomycin (口), and $10 \mathrm{ng} / \mathrm{ml}$ anti-CD4 and $50 \mathrm{U} / \mathrm{ml} \mathrm{rIL-} \alpha(\bullet)$. The techniques for separation and activation of fresh $\mathrm{T}$ lymphocytes are described in Methods. The values are the mean of 10 independent experiments. 
eightfold ( $243 \mathrm{pmol} / \mathrm{min}$ per $\mathrm{mg}$ ) by $15 \mathrm{~min}$, and returned toward baseline at 60 min (Fig. 2). A bimodal curve with a minor peak at $5 \mathrm{~min}$ and a major peak at $15 \mathrm{~min}$ was consistently observed. However, ionomycin alone failed to stimulate PKA activity (data not shown). When the agonist pair antiCD3- $\epsilon$ and PMA was used, the peak PKA activity of fresh T cells occurred at an intermediate time of $10 \mathrm{~min}$ (data not shown ). Thus, activation of T cells via the TCR/CD3 complex and IL-1R or by direct stimulation of PKC and $\left[\mathrm{Ca}^{2+}\right]_{i}$ stimulated PKA phosphotransferase activity at $1 \mathrm{~min}$. The times of peak PKA activity varied slightly, but consistently, depending on the agonists used to activate $\mathrm{T}$ cells.

$P K A-I$ isozyme activity is an early event in T cell activation. To determine whether there is preferential activation of a PKA isozyme, primary $\mathrm{T}$ cells were cultured in the absence or presence of anti-CD3- $\epsilon$ and rIL- $1 \alpha$ for $5 \mathrm{~min}$; the cells were promptly sonicated at $4^{\circ} \mathrm{C}$; and the cellular homogenates were fractionated via sequential DE52-cellulose and CM-sephadex chromatography. Table I shows the total phosphotransferase activities for the PKA-I and PKA-II isozymes as well as the free $\mathrm{C}$ subunit activities before and $5 \mathrm{~min}$ after $\mathrm{T}$ cell activation by anti-CD3- $\epsilon$ and rIL- $1 \alpha$ in eight independent experiments. Compared with nonactivated $\mathrm{T}$ cells, there was a statistically significant, mean $42.1 \%$ decrease in PKA-I isozyme activity, a significant increase of $165 \%$ in free $\mathrm{C}$ subunit activity, but only a 7\% change in PKA-II activity. The increase in PKA-II activity is not significantly different from PKA-II activity in nonactivated T cells. The preferential stimulation of the PKA-I isozyme resulted in a reduction of the ratio of PKA-I to PKA-II activity from 4.0:1 in nonactivated cells to 2.0:1 in activated $\mathrm{T}$ cells.

A representative experiment demonstrating preferential activation of the PKA-I isozyme after activation of $\mathrm{T}$ cells by anti-CD3- $\epsilon$ and rIL- $\alpha$ is shown in Fig. 3. Nonactivated T cells had a total PKA-I activity of $528 \mathrm{pmol} / \mathrm{min}$, a total PKA-II activity of $136 \mathrm{pmol} / \mathrm{min}$, and a basal free $\mathrm{C}$ subunit activity of
$78 \mathrm{pmol} / \mathrm{min}$, yielding a ratio of PKA-I to PKA-II isozyme activity of 3.9:1. T cells activated for $5 \mathrm{~min}$ with anti-CD3- $\epsilon$ and rIL- $1 \alpha$ showed a $41.3 \%$ reduction in PKA-I activity to 310 $\mathrm{pmol} / \mathrm{min}$, indicating activation of a portion of PKA-I by endogenous cAMP. Only a $9.5 \%$ increment in PKA-II isozyme activity was observed. The preferential stimulation of PKA-I resulted in a reduction of the ratio of PKA-I to PKA-II activity to $2.0: 1$. The $C$ subunit activity increased $210 \%$, from 78 to 242 $\mathrm{pmol} / \mathrm{min}$, indicating that free $\mathrm{C}$ subunit was released from PKA-I after its activation.

The activation of fresh T cells by $10 \mathrm{ng} / \mathrm{ml}$ PMA and 0.5 $\mu \mathrm{M}$ ionomycin also activated the PKA-I isozyme. The data are shown in Table I. At $15 \mathrm{~min}$ after activation, there was a statistically significant, mean $52.5 \%$ reduction of PKA-I isozyme activity, a significant increase of $232 \%$ in free $C$ subunit activity, but $<2 \%$ decrease in PKA-II isozyme activity. The change in PKA-II activity was not statistically significant. The activation of PKA-I resulted in a substantial reduction in the ratio of PKA-I to PKA-II activity to 1.9:1. Thus, the concomitant reduction in the ratio of PKA-I to PKA-II activity and elevation of free $C$ subunit activity produced by either agonist pair demonstrates that the PKA-I isozyme is preferentially activated.

Parallel experiments were performed with the quiescent GK606 cell line, which has a ratio of PKA-I to PKA-II activity of $4.0: 1$. Activation of the cell line by anti-CD3- $\epsilon$ and rIL- $\alpha$ for 5 min resulted in a 46\% reduction in PKA-I activity from 237 to $128 \mathrm{pmol} / \mathrm{min}$, yielding a ratio of PKA-I to PKA-II activity of $1.4: 1$. There was $<5 \%$ increase in the PKA-II activity. The free C subunit activity increased $109 \%$ from 63 to $132 \mathrm{pmol} /$ min. Similarly, activation of the cell line with $10 \mathrm{ng} / \mathrm{ml}$ PMA and $0.5 \mu \mathrm{M}$ ionomycin for $15 \mathrm{~min}$ caused a $64 \%$ decline in the PKA-I isozyme activity to $85 \mathrm{pmol} / \mathrm{min}$, giving a ratio of PKA-I to PKA-II activity of 1.1:1. No change in the PKA-II activity was observed. The mean free $C$ subunit activity rose $370 \%$ to $297 \mathrm{pmol} / \mathrm{min}$. The decline in PKA-I and increase in $\mathrm{C}$ subunit activities after activation of the cell line with both

Table I. T Cell Activation by Anti-CD3-€ and rIL-1 $\alpha$ or PMA and Ionomycin Preferentially Activates the PKA-I Isozyme

\begin{tabular}{|c|c|c|c|c|}
\hline \multirow[b]{2}{*}{ Agonist pair } & \multicolumn{3}{|c|}{ PKA phosphotransferase activity* } & \multirow{2}{*}{$\begin{array}{l}\text { Mean ratio } \\
\text { of PKA-I to } \\
\text { PKA-II activity }\end{array}$} \\
\hline & PKA-I & PKA-II & $\begin{array}{c}\text { Free } C \\
\text { subunit }\end{array}$ & \\
\hline \multicolumn{5}{|c|}{$\mathrm{pmol} / \mathrm{min}$} \\
\hline \multirow[t]{2}{*}{ None } & $484 \pm 47^{\ddagger}$ & $120 \pm 19^{\ddagger}$ & $91 \pm 11$ & 4.0:1 \\
\hline & {$[327-618]^{\S}$} & {$[56-153]$} & {$[65-140]$} & {$[3.1: 1-6.2: 1]$} \\
\hline \multirow[t]{2}{*}{ Anti-CD3- $\epsilon+$ rIL-1 $\alpha$} & $280 \pm 53^{\| \prime}$ & $137 \pm 12$ & $241 \pm 44^{\pi}$ & $2.0: 1$ \\
\hline & {$[118-377]$} & [98-191] & {$[101-379]$} & {$[1.1: 1-3.2: 1]$} \\
\hline \multirow[t]{2}{*}{ PMA + ionomycin } & $230 \pm 64 \|$ & $118 \pm 30$ & $302 \pm 25^{\prime}$ & $1.9: 1$ \\
\hline & {$[135-464]$} & {$[52-244]$} & [89-375] & {$[1.1: 1-2.7: 1]$} \\
\hline
\end{tabular}

Eight independent experiments using primary T lymphocytes. * The total PKA phosphotransferase activity (PKA-I + PKA-II + C subunit) was $695 \mathrm{pmol} / \mathrm{min}$ for the nonactivated cells, $658 \mathrm{pmol} / \mathrm{min}$ for cells activated with anti-CD3- $\epsilon+$ and rIL- $1 \alpha$, and $650 \mathrm{pmol} / \mathrm{min}$ for cells activated with PMA and ionomycin. Compared with nonactivated T cells, the percent decrease in total PKA phosphotransferase activity after activation with anti-CD3- $\epsilon$ and rIL- $1 \alpha$ was 5.3 and after activation with PMA and ionomycin was 6.5. The differences in total PKA activities after ligand-induced $\mathrm{T}$ cell activation are not significantly different from that of nonactivated T cells. ${ }^{\ddagger}$ The activity is the total PKA-I or PKA-II phosphotransferase activity. The activities for the PKA-I and PKA II isozymes and free C subunit are given as the mean \pm SEM. $\$$ Numbers in brackets are the ranges of phosphotransferase activities or of activity ratios. "Comparisons of total PKA-I activities: nonactivated T cells vs. T cells activated with anti-CD3- $\epsilon$ and rIL- $1 \alpha, P=0.01$; nonactivated T cells vs. T cells activated with PMA and Ionomycin, $P=0.009$. ' Comparisons of free $\mathrm{C}$ subunit activities: nonactivated T cells vs. T cells activated with anti-CD3- $\epsilon$ and rIL-1 $\alpha, P=0.002$; nonactivated T cells vs. T cells activated with PMA and ionomycin, $P<0.001$. 


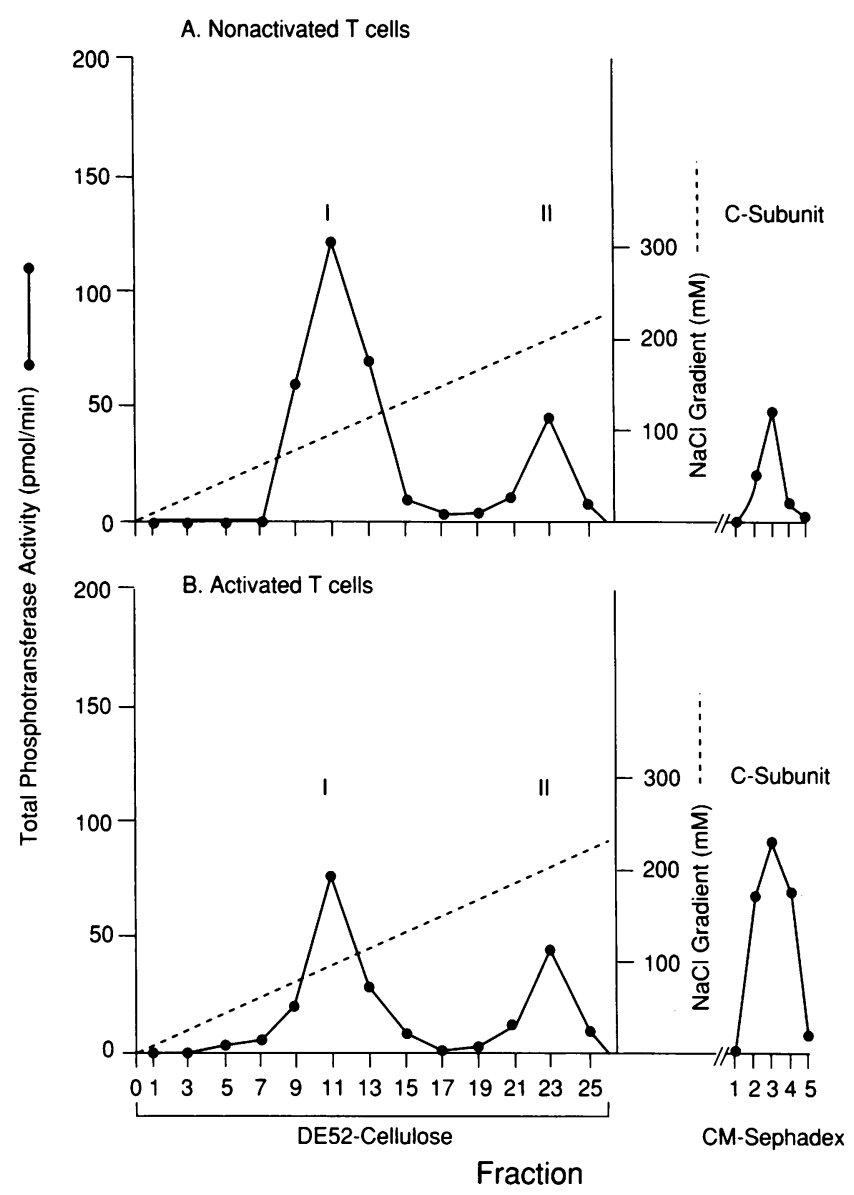

Figure 3. Activation of T cells by anti-CD3- $\epsilon$ and rIL-1 $\alpha$ preferentially activates the PKA-I isozyme. T cells were incubated in the absence or presence of anti-CD3- $\epsilon$ and rIL- $1 \alpha$ for $5 \mathrm{~min}$, the cells were gently homogenized, and $1 \mathrm{mg}$ of cellular homogenate was applied to a 1-ml DE52-cellulose column. After elution of the DE52-cellulose column with a buffered salt gradient, the CM-sephadex column was eluted with $0.55 \mathrm{M} \mathrm{NaCl}$ in buffer. The fractions from both columns were assayed for PKA phosphotransferase activity, as described in the Methods. The peak PKA-I activities eluted in fraction 11 whereas the peak PKA-II activities eluted in fraction 23. $(A)$ In the nonactivated T cells, the total PKA-I isozyme phosphotransferase activity was 528 $\mathrm{pmol} / \mathrm{min}$, the total PKA-II activity was $136 \mathrm{pmol} / \mathrm{min}$, and the free basal C subunit activity was $78 \mathrm{pmol} / \mathrm{min}$. PKA-I + PKA-II + C subunit $=742 \mathrm{pmol} / \mathrm{min}$. $(B)$ After T cell activation, the total PKA-I activity was $310 \mathrm{pmol} / \mathrm{min}$, the total PKA-II activity was $149 \mathrm{pmol} /$ $\mathrm{min}$, and the free $\mathrm{C}$ subunit activity was $242 \mathrm{pmol} / \mathrm{min}$. PKA-I + PKA-II $+\mathrm{C}$ subunit $=701 \mathrm{pmol} / \mathrm{min}$. Compared with nonactivated $\mathrm{T}$ cells, the percent decrease in overall PKA phosphotransferase activity after activation with anti-CD3- $\epsilon$ and rIL- $1 \alpha$ was 5.5 . This experiment is representative of eight independent experiments.

agonist pairs paralleled the changes observed in fresh $\mathrm{T}$ cells. Together, the data suggest that activation of $T$ cells stimulates PKA-I phosphotransferase activity.

The reduction of PKA-I activity, increase in free $C$ subunit activity, and stable PKA-II activity after $\mathrm{T}$ cell activation by either agonist pair was not associated with a significant change in the total PKA phosphotransferase activity (Table I).

$S$ phase growth of the GK606 line resulted in persistent activation of the PKA-I isozyme. The mean PKA-I and PKAII activities were 162 and $125 \mathrm{pmol} / \mathrm{min}$, respectively, yielding a ratio of PKA-I to PKA-II activity of 1.2:1. When cultured in the absence of rIL-2 and in the presence of low concentrations of FCS ( $2 \%$ FCS) to return the cells to the $G_{0} / G_{1}$ phase of the cell cycle, the total PKA-I activity rose to a mean $435 \mathrm{pmol} /$ min. The mean total PKA-II activity was $108 \mathrm{pmol} / \mathrm{min}$. Thus, the ratio of PKA-I to PKA-II activity returned to 4.0:1.

Requirement for PKA-I isozyme activation for IL-2 $m R N A$ transcription. An integral step in T cell activation is the transcription of the IL-2 gene that regulates IL-2 production before and during mitogenesis (5). To determine whether activation of PKA-I is required for transcription of this gene, we used inhibitors that prevent PKA or PKC activation. Initially, we quantified the effects of PKA and PKC inhibitors on the activation of PKA by both agonist pairs in fresh $T$ cells and the GK606 cell line. Cells were activated with anti-CD3- $\epsilon$ and rIL$1 \alpha$ or $10 \mathrm{ng} / \mathrm{ml} \mathrm{PMA}$ and $0.5 \mu \mathrm{M}$ ionomycin in the absence or presence of a cell-permeable protein kinase inhibitor: the $(R p)$ diastereomer of adenosine cyclic $3^{\prime}, 5^{\prime}$-phosphorothioate [RpcAMPS] or 1-(5-isoquinolinesulfonyl)-2-methylpiperazine (H-7). Rp-cAMPS is a specific inhibitor of PKA that competitively impedes the binding of cAMP to the RI and RII subunits of PKA-I and PKA-II, respectively (25). H-7 is an inhibitor of PKC that competitively blocks the binding of ATP to the C subunit of the enzyme (19). Activation of fresh $T$ cells with anti-CD3- $\epsilon$ and rIL- $1 \alpha$ increased PKA phosphotransferase activity $151 \%$ at $5 \mathrm{~min}$; T cells activated with PMA and ionomycin exhibited a $124 \%$ increase in PKA activity at $15 \mathrm{~min}$. Similar results were obtained when the $T$ cell line was activated in parallel analyses. Rp-cAMPS inhibited PKA activity $91.5 \%$ at $5 \mathrm{~min}$ in T cells activated with anti-CD3- $\epsilon$ and rIL- $1 \alpha$ and 98.3\% at $15 \mathrm{~min}$ in $\mathrm{T}$ cells activated with PMA and ionomycin (Table II). These results demonstrate that PKA activation by either agonist pair can be effectively inhibited.

Activation of the quiescent GK606 T cell line and fresh T cells by either agonist pair induced transcription of IL-2 mRNA compared with the nonactivated $\mathrm{T}$ cell line or fresh $\mathrm{T}$ cells (Fig. $1 A$, lanes $2-4$; cell line). $\beta$-Actin mRNA expression was constitutively present and unaffected by the state of $\mathrm{T}$ cell activation in both the $\mathrm{T}$ cell line and fresh $\mathrm{T}$ cells (Fig. $1 B$, lanes 2-4; cell line) ( $n=5$ experiments each).

The effect of inhibiting PKA activity by Rp-cAMPS on the expression of IL-2 mRNA after activation with anti-CD3- $\epsilon$ and rIL- $1 \alpha$ was studied in the GK606 cell line. Inhibition of PKA activation did not block expression of IL-2 mRNA (Fig. $1 A$, lane 5). By contrast, activation of the $\mathrm{T}$ cell line in the presence of $\mathrm{H}-7$ totally blocked expression of IL-2 mRNA (Fig. $1 A$, lane 7). Similarly, activation of the T cell line by $10 \mathrm{ng} / \mathrm{ml}$ PMA and $0.5 \mu \mathrm{M}$ ionomycin in the presence of Rp-cAMPS did not

Table II. Activation of Total PKA Phosphotransferase Activity by anti-CD3- $\epsilon$ and rIL-1 $\alpha$ or PMA and Ionomycin Is Inhibitable by Rp-cAMPS

\begin{tabular}{|c|c|c|}
\hline Agonist pair & $\begin{array}{c}\text { Total PKA } \\
\text { phosphotransferase } \\
\text { activity }\end{array}$ & $\begin{array}{c}\text { Inhibition by } \\
500 \mu \mathrm{M} \text { Rp-cAMPS }\end{array}$ \\
\hline & $\begin{array}{l}\text { pmol/min per } \\
\text { mg protein }\end{array}$ & $\%$ \\
\hline Anti-CD3- $\epsilon+$ rIL-1 $\alpha$ & $265 \pm 24$ & $91.5 \pm 7.5$ \\
\hline PMA + ionomycin & $252 \pm 16$ & $98.3 \pm 0.7$ \\
\hline
\end{tabular}

Values are means \pm SEM. 
inhibit expression of IL-2 mRNA (Fig. $1 A$, lane 6 ), whereas IL-2 mRNA expression in response to activation of the $T$ cell line by PMA and ionomycin was completely inhibited by $\mathrm{H}-7$ (Fig. $1 A$, lane 8 ). Fig. $1 B$ demonstrates that $\beta$-actin mRNA expression was unaffected by the inhibitors of PKA (RpcAMPS) or PKC (H-7) (lanes 5-8). These results suggest that the activation of PKA-I does not appear to be required for the transcription of IL-2 mRNA.

PKA-I isozyme phosphorylates membrane-associated proteins. The very early activation of the PKA-I isozyme after T cell activation with both agonist pairs prompted us to determine whether proteins were phosphorylated by this isozyme. The PKA-I isozyme is predominantly associated with the plasma membrane of human $T$ lymphocytes (12). Thus, cells labeled with ${ }^{32} \mathrm{P}_{\mathrm{i}}$ were treated for various intervals with $2.5 \mathrm{mM}$ $\mathrm{Bt}_{2} \mathrm{cAMP}$ in the absence or presence of the cell-permeable cyclic nucleotide protein kinase inhibitor, $\mathrm{H}-8$; plasma membrane was isolated; the membrane fragments were separated by 12\% 1-D PAGE; and autoradiographs were prepared (18). The autoradiograph shown in figure 4 demonstrates PKA-I-catalyzed phosphorylation of several proteins, p14.2, p17.7, p20.8, p21.6, p38.7, and p48. Phosphorylation was observed within $0.5 \mathrm{~min}$. p17.7 shows increasing phosphorylation to $10 \mathrm{~min}$ and dephosphorylation at $20 \mathrm{~min}$. H-8 inhibited PKA-I-catalyzed phosphorylation of membrane-associated proteins.

\section{Discussion}

The function of PKA during the early biochemical events leading to the activation of human $T$ lymphocytes has not been established. The recent recognition that the PKA-I isozyme is associated with the plasma membrane (12) raised the possibility that this isozyme may phosphorylate membrane-associated proteins required for early biochemical events and/or regulation of IL-2 gene transcription during $T$ cell activation. The data presented herein demonstrate that treatment of either fresh human $T$ cells or a quiescent, nonmalignant human $\mathrm{CD}^{+}{ }^{+} \mathrm{T}$ cell line with the agonist pairs anti-CD3- $\epsilon$ and rIL-1 $\alpha$ or PMA and ionomycin stimulated PKA phosphotransferase activity within $1 \mathrm{~min}$.

The activation of PKA phosphortransferase activity in $T$ cells depended on the presence of both anti-CD3- $\epsilon$ and rIL-1 $\alpha$. At the concentrations of the ligands used, PKA activation required the concomitant occupancy of both the IL-1R and TCR/CD3 complex by their respective ligands, for neither anti-CD3- $\epsilon$ nor rIL- $1 \alpha$ alone provided a sufficient stimulus to activate the enzyme. Although concentrations of anti-CD3- $\epsilon$ 100 -fold greater can stimulate cAMP production, promote occupancy of cAMP receptors on PKA $R$ subunits, and induce capping of CD3 on normal T cells (18), cells cannot proliferate without a costimulatory signal $(5,26)$. Under the conditions used, rIL- $1 \alpha$ provided the costimulatory signal and reduced the concentration of anti-CD3- $\epsilon$ needed to stimulate PKA activation. Although our results concur with previous analyses that concluded that IL-1 provides a cooperative signal for normal human T cell activation (27), our data indicate that IL- $1 \alpha$ does not directly initiate a signal that traverses the AC/cAMP/PKA pathway in normal T cells. Interestingly, IL-1 induces cAMP production and activation of an NF- $\kappa$ B-like DNA-binding protein in a human pre-B cell (28) and a human natural killer cell line (29), but neither increases cAMP nor activates NF- $\kappa$ B in a human $\mathrm{T}$ cell line $(30,31)$. Our inability to detect PKA phosphotransferase activity after exposure of $\mathrm{T}$ cells to a wide range of rIL- $1 \alpha$ concentrations indirectly indicates that cAMP levels are not increased and would suggest that the cytokine probably initiates signals that traverse other pathways $(30,32)$. Recent evidence implicating a novel $G$ protein in the coupling of IL-1R to an alternative pathway (33) and the activation of a protein tyrosine kinase( $\mathrm{s}$ ) by IL- $\alpha$ in a murine T cell line (34) provide support for this thesis. Because IL-1 activates discrete biochemical pathways in different human and murine cell lines $(28,29,31-37)$, its precise mechanism of action in normal human $\mathrm{T}$ lymphocytes requires further analysis.

$T$ cell activation was also induced by the agonist pair of PMA and ionomycin. This agonist pair promotes the rapid increase in $\left[\mathrm{Ca}^{2+}\right]_{\mathrm{i}}$ and direct activation of $\mathrm{PKC}$ that induces

\section{MINUTES}

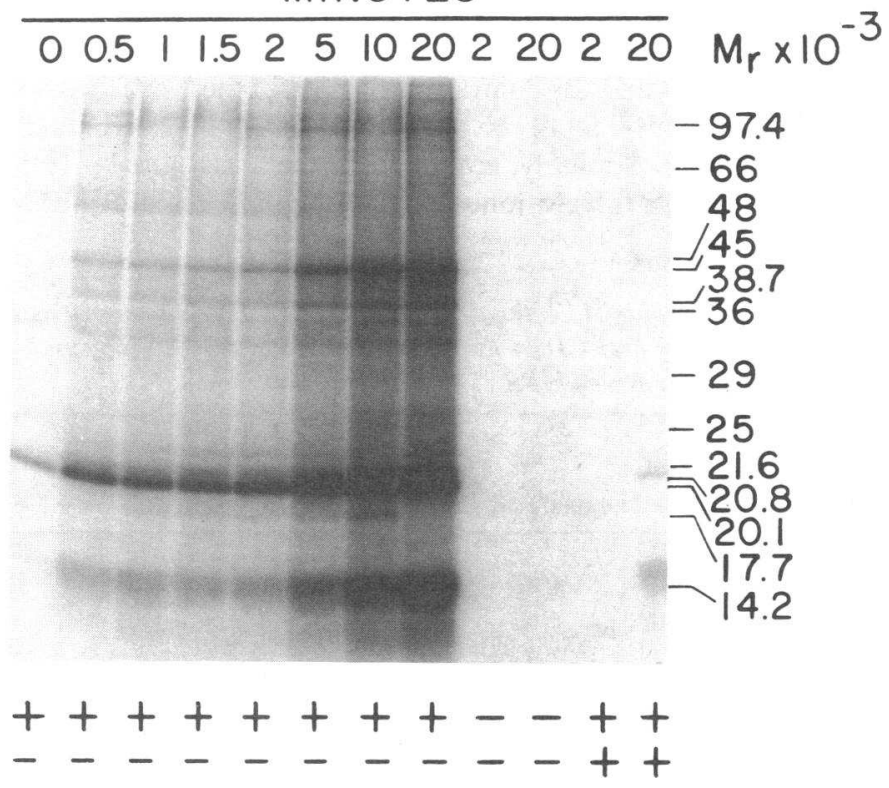

Figure 4. cAMP-inducible, type I PKA isozyme-dependent phosphorylation of $T$ lymphocyte plasma membrane-associated proteins. Normal peripheral blood $\mathrm{T}$ lymphocytes were incubated with ${ }^{32} \mathrm{P}_{\mathrm{i}} 0.5$ $\mathrm{mCi} / \mathrm{ml}$ for $45 \mathrm{~min}$ at $37^{\circ} \mathrm{C}$, washed, and incubated in the absence (lanes 9 and 10 ) or presence of 2.5 $\mathrm{mM} \mathrm{bt}{ }_{2} \mathrm{cAMP}$ and $100 \mu \mathrm{M}$ RO20-1724, a cAMP phosphodiesterase inhibitor (lanes $1-8$ ), or $\mathrm{bt}_{2} \mathrm{cAMP}$ and $\mathrm{RO} 20-1724$ and $100 \mu \mathrm{M} \mathrm{H}-8$ (lanes 11 and 12) at $37^{\circ} \mathrm{C}$ for time intervals to $20 \mathrm{~min}$. Membrane fractions of $\mathrm{T}$ cells were then prepared as previously described (12). Membrane from $5.2 \times 10^{6}$ cells containing $20 \mu \mathrm{g}$ protein was loaded onto $12 \% 1-\mathrm{D}$ polyacrylamide gels and subjected to electrophoresis. Autoradiographs were developed after $72 \mathrm{~h}$ at $-70^{\circ} \mathrm{C}$. Incorporation of ${ }^{32} \mathrm{P}$ was quantified by scanning laser densitometry of bands. This autoradiograph is representative of three independent experiments. 
initiation of IL-2 mRNA transcription and, ultimately, T cell proliferation $(4,5,38)$. However, we observed that PMA and ionomycin also activated PKA. Although PMA alone activates PKC (38), neither the $\mathrm{Ca}^{2+}$ ionophore nor the phorbol ester alone could activate PKA. When the data using both agonist pairs were pooled, it became apparent that effective activation of PKA requires either cross-linking of CD3- $\epsilon$ by anti-CD3- $\epsilon$ in the presence of rIL- $1 \alpha$ or both the phorbol ester and ionophore.

Sequential DE52-cellulose and CM-sephadex column chromatography separates PKA into its constitutive PKA-I and PKA-II isozymes and captures the free, endogenous $C$ subunit (20). Using this technique, we demonstrated that the PKA activity observed between 1 and $5 \mathrm{~min}$ after activation of fresh $T$ cells by either agonist pair was the result of preferential activation of the PKA-I isozyme. There was no significant change in the PKA-II activity. This result implies that the agonist pairs induce AC activation, yielding enhanced cAMP production and occupancy of RI subunits by cAMP. The activation and partial use of the PKA-I isozyme causes the ratio of PKA-I to PKA-II isozyme activity to drop significantly from 3.1:1-6.2:1 to 1.1:1-3.2:1. Similarly, activation of the GK606 line, a nonmalignant human $\mathrm{CD}^{+} \mathrm{T}$ cell line, with both agonist pairs also produced a significant reduction in the PKA-I to PKA-II activity ratio. Because the reduction in PKA-I activity and concomitant increase in free $\mathrm{C}$ subunit activity were not associated with either a significant change in PKA-II activity or total PKA phosphotransferase activity, it is reasonable to conclude that the decline in PKA-I activity is due to the activation of a portion of the PKA-I holoenzyme, leaving the remaining isozyme in the holoenzyme form and resulting in the release of free $\mathrm{C}$ subunit.

The polyphosphoinositide/ $\mathrm{Ca}^{2+} / \mathrm{PKC}$ pathway can also stimulate PKA activity in other cell types (39-44). This observation suggests that the polyphosphoinositide/ $\mathrm{Ca}^{2+} / \mathrm{PKC}$ and AC/cAMP/PKA are interdependent pathways. Although the precise mechanism(s) by which PMA and ionomycin activate PKA-I isozyme activity in the human T lymphocyte is uncertain, three potential mechanisms could be operative. PKC could phosphorylate the $\mathrm{C}$ subunit of $\mathrm{AC}$, directly activating the enzyme (42). A second potential mechanism is by phosphorylation of the $\mathrm{G}_{\mathrm{i} \alpha}$ subunit by PKC (45). The $\alpha$ subunit of $\mathrm{G}_{i}$ inhibits $A C$ catalysis; phosphorylation of $G_{i \alpha}$ may block its inhibitory function of $\mathrm{AC}$, thereby permitting $\mathrm{AC}$ catalysis. Yet a third potential mechanism is the phosphorylation of the $G_{s \alpha}$ subunit by PKC (46). Because the interdependence between the AC/cAMP/PKA and polyphosphoinositide/ $\mathrm{Ca}^{2+} / \mathrm{PKC}$ pathways in $\mathrm{T}$ lymphocytes may be regulated, in part, by phosphorylation/dephosphorylation of receptor-associated $G$ protein subunits, it will be of practical importance to define more precisely the mechanism of phorbol ester-induced PKA activation. Moreover, other, as-yet-unidentified, mechanisms could account for the apparent interdependence of the pathways.

PKA-I isozyme activation did not appear to be required for initiation of IL-2 gene transcription. Inhibition of PKA activity and, by inference, subsequent substrate phosphorylation, by Rp-cAMPS did not impede expression of IL-2 mRNA. By contrast, inhibition of PKC activity by $\mathrm{H}-7$ totally blocked transcription of the IL- 2 gene, but not the $\beta$-actin gene. These data suggest that PKA-I-catalyzed protein phosphorylation may not be directly involved in the initiation of IL-2 gene transcription. However, PKA-I did result in the immediate phosphory- lation of multiple membrane-associated proteins with molecular masses between 14 and $48 \mathrm{kD}$. Although the identities of these protein substrates for PKA-I are not yet known, it is conceivable that one or more of these phosphoproteins may have a role in the very early events of $T$ cell activation. Thus, identification of these proteins may provide insight into the specific role of PKA-I in early $\mathrm{T}$ cell activation events.

It is possible, however, that basal PKA activity may be necessary and is permissive for the transcription of IL-2 mRNA. The precedent for this supposition derives from experiments performed in the EL-4 and JEG-3 cell lines. In an analysis of the role of IL- 1 on activation of the AP- 1 transcription factor in the EL-4 cell line, IL-1 alone neither increases intracellular cAMP levels nor induces AP-1 DNA binding activity. However, the combination of IL-1 and a phorbol ester promotes AP-1 activity in the absence of a rise in cAMP levels. In spite of the absence of an apparent role for the AC/cAMP/PKA pathway, transfection of a cDNA encoding a protein kinase inhibitor (PKI) specific for PKA into EL-4 cells abrogates the capacity of IL-1 and a phorbol ester to activate AP-1 DNA binding activity (36). Similarly, in the JEG-3 cell line, expression of the human chorionic gonadotropin- $\alpha$ subunit gene also depends on basal PKA activity for transfection of plasmids encoding PKI abolishes transcription of the gene (47). The $>92 \%$ inhibition of PKA phosphotransferase activity by Rp-cAMPS leaves basal PKA activity (Table II). Thus, a role for basal PKA-dependent protein phosphorylation in the regulation of IL-2 gene transcription cannot be entirely excluded.

In conclusion, this is the first demonstration that an isozyme of PKA is associated with the very early $T$ cell activation events that ultimately result in mitosis and immune effector activities. Hence, the PKA-I isozyme could be regarded as an antigen- or mitogen-stimulated protein kinase that serves to phosphorylate membrane-associated proteins. Furthermore, this result implies that the PKA-I isozyme works in concert with other early-acting protein kinases, including the p59 fynT and p56 ${ }^{\text {lck }}$ tyrosine kinases (48), and PKC isozymes (5) to convey a receptor-initiated signal to different subcellular compartments. The demonstration that PKA-I is associated with early signaling events revises the current concept that PKA conveys an "off" signal that ultimately inhibits mitosis and certain $\mathrm{T}$ cell effector activities such as IL-2 production and cytotoxicity (11).

\section{Acknowledgments}

We thank Gregory S. Shelness for assistance in sequencing the amplified PCR products; Charles J. Malemud for helpful discussions during the course of these experiments; Islam U. Khan and Steven B. Mizel for review of the manuscript; and Talat Haqqi for technical assistance.

This work was supported in part by a grant from the National Institutes of Health (AR-39501) and a Biomedical Science grant from the Arthritis Foundation.

\section{References}

1. Unanue, E. R., and P. M. Allen. 1987. The basis for the immunoregulatory role of macrophages and other accessory cells. Science (Wash. DC). 236:551557.

2. Yang, S. Y., S. Chouaib, and B. Dupont. 1986. A common pathway for T lymphocyte activation involving both the CD3-Ti complex and CD2 sheep erythrocyte receptor determinants. J. Immunol. 137:1097-1100.

3. Kawakami, K. Y. Yamamoto, K. Kakimoto, and K. Onoue. 1989. Requirement for delivery of signals by physical interaction and soluble factors from 
accessory cells in the induction of receptor-mediated T-cell proliferation: effectiveness of IFN-gamma modulation of accessory cells for physical interaction with T cells. J. Immunol. 142:1818-1825.

4. Crabtree, G. R. 1989. Contingent genetic regulatory events in T lymphocyte activation. Science (Wash. DC). 243:355-361.

5. Berry, N., and Y. Nishizuka. 1990. Protein kinase $C$ and T cell activation. Eur. J. Biochem. 189:205-214.

6. Palacios, R. 1985. Mechanisms by which accessory cells contribute in growth of resting T lymphocytes initiated by OKT3 antibody. Eur. J. Immunol. 15:645-651.

7. Cantrell, D. A., A. A. Davies, and M. J. Crumpton. 1985. Activators of protein kinase $\mathrm{C}$ down-regulate and phosphorylate the $\mathrm{T} 3$ / T-cell antigen receptor complex of human T lymphocytes. Proc. Natl. Acad. Sci. USA. 82:81588162 .

8. Cantrell, D., A. A. Davies, M. Londei, M. Feldman, and M. J. Crumpton 1987. Association of phosphorylation of the T3 antigen with immune activation of T lymphocytes. Nature (Lond.). 325:540-542.

9. Samelson, L. E., M. D. Patel, A. M. Weissman, J. B. Harford, and R. D. Klausner. 1986. Antigen activation of murine T cells induces tyrosine phosphorylation of a polypeptide associated with the $T$ cell antigen receptor. Cell. $46: 1083$ 1090.

10. Klausner, R. D., J. J. O'Shea, H. Luong, P. Ross, J. A. Bluestone, and L. E Samelson. 1987. T cell receptor tyrosine phosphorylation: variable coupling for different activating ligands. J. Biol. Chem. 262:12654-12659.

11. Kammer, G. M. 1988. The adenylate cyclase-cAMP-protein kinase A pathway and regulation of the immune response. Immunol. Today. 9:222-229.

12. Hasler, P., J. J. Moore, and G. M. Kammer. 1992. Human T lymphocyte cAMP-dependent protein kinase: subcellular distributions and activity ranges of type I and type II isozymes. FASEB (Fed. Am. Soc. Exp. Biol.) J. 6:2735-2741.

13. Lohmann, S. M., and U. Walter. 1984. Regulation of the cellular and subcellular concentrations and distribution of cyclic nucleotide-dependent protein kinases. Adv. Cyclic Nucleotide Protein Phosphorylation Res. 18:63-117.

14. Byus, C. V., F. R. Klimbel, D. O. Lucas, and D. H. Russell. 1977. Type I and type II cyclic AMP-dependent protein kinase as opposite effectors of lymphocyte mitogenesis. Nature (Lond.). 268:63-64.

15. Tortora, G., H. Yokozaki, S. Pepe, T. Clair, and Y. S. Cho-Chung. 1991. Differentiation of HL-60 leukemia by type I regulatory subunit antisense oligodeoxynucleotide of cAMP-dependent protein kinase. Proc. Natl. Acad. Sci. USA 88:2011-2015.

16. Hasler, P., L. A. Schultz, and G. M. Kammer. 1990. Defective cAMP-dependent phosphorylation of intact T lymphocytes in active systemic lupus erythematosus. Proc. Natl. Acad. Sci. USA. 87:1978-1982.

17. Braylan, R. C., N. A. Benson, V. Nourse, and H. S. Kruth. 1982. Correlated analysis of cellular DNA, membrane antigens and light scatter of human lymphoid cells. Cytometry. 2:337-343.

18. Kammer, G. M., C. A. Boehm, S. A. Rudolph, and L. A. Schultz. 1988 Mobility of the human T lymphocyte surface molecules CD3, CD4 and CD8: regulation by a cAMP-dependent pathway. Proc. Natl. Acad. Sci. USA. 85:792796.

19. Hidaka, H., and R. Kobayashi. 1992. Pharmacology of protein kinase inhibitors. Annu. Rev. Pharmacol. Toxicol. 32:377-397.

20. Livesey, S. A., and T. J. Martin. 1988. Selective activation of the cAMPdependent protein kinase isozymes. Methods Enzymol. 159:105-118.

21. Bradford, M. M. 1976. A rapid and sensitive method for the quantitation of microgram quantities of protein utilizing the principle of protein-dye binding. Anal. Biochem. 72:248-254.

22. Chomczynski, P. 1990. Single-step RNA isolation from cultured cells or tissues. In Current Protocols in Molecular Biology. F. M. Ausubel, R. Brent, R. E Kingston, D. D. Moore, J. G. Seidman, J. A. Smith, and K. Struhl, editors. John Wiley \& Sons, New York. 4.2.4.

23. Kawasaki, E. S. 1990. Amplification of RNA. In PCR Protocols: A Guide to Methods and Applications. M. A. Innes, D. H. Gelfand, J. J. Sninsky, and T. J. White, editors. Academic Press, New York. 21-27.

24. Brenner, C. A., A. W. Tam, P. A. Nelson, E. G. Engleman, N. Suzuki, K. E. Fry, and J. W. Larrick. 1989. Message amplification phenotyping (MAPPing): a technique to simultaneously measure multiple mRNAs from small numbers of cells. Biotechniques. 7:1096-1103.

25. Rothermel, J. D., B. Jastorff, and L. H. P. Botelho. 1984. Inhibition of glucagon-induced glycogenolysis in isolated rat hepatocytes by the Rp diastereomer of adenosine cyclic 3',5'-phosphorothioate. J. Biol. Chem. 259:81518155.
26. Kammer, G. M., R. Kurrasch, and J. J. Scillian. 1984. Capping of the surface OKT 3 binding molecule prevents the $\mathrm{T}$-cell proliferative response to antigens: evidence that this molecule conveys the activation signal. Cell. Immunol. 87:284-294.

27. Weiss, A., and J. B. Imboden. 1987. Cell surface molecules and early events involved in human T lymphocyte activation. Adv. Immunol. 41:1-38.

28. Shirakawa, F., M. Chedid, J. Suttles, B. A. Pollock, and S. B. Mizel. 1989. Interleukin 1 and cyclic AMP induce $\kappa$ immunoglobulin light-chain expression via activation of an NF- $k$ B-like DNA-binding protein. Mol. Cell. Biol. 9:959-964.

29. Shirakawa, F., U. Yamashita, M. Chedid, and S. B. Mizel. 1988. Cyclic AMP_an intracellular second messenger for interleukin 1. Proc. Natl. Acad. Sci. USA. 85:8201-8205.

30. Didier, M., C. Aussel, C. Pelassy, and M. Fehlmann. 1988. IL-1 signaling for IL-2 production in T cells involves a rise in phosphatidylserine synthesis. $J$. Immunol. 141:3078-3080.

31. Osborn, L., S. Kunkel, and G. J. Nabel. 1989. Tumor necrosis factor alpha and interleukin 1 stimulate the human immunodeficiency virus enhancer by activation of the nuclear factor kappa B. Proc. Natl. Acad. Sci. USA. 86:23362340.

32. O’Neill, L. A. J., T. A. Bird, and J. Saklatvala. 1990. Interleukin 1 signal transduction. Immunol. Today. 11:392-393.

33. Ray, K., N. Thompson, N. Kennard, P. Rollins, S. Grenfell, S. Witham, N. Smithers, and R. Solari. 1992. Investigation of guanine-nucleotide-binding protein involvement and regulation of cyclic AMP metabolism in interleukin 1 signal transduction. Biochem. J. 282:59-67.

34. Munoz, E., A. Zubiaga, C.-K. Huang, and B. T. Huber. 1992. Interleukin1 induces protein tyrosine phosphorylation in T cells. Eur. J. Immunol. 22:13911396.

35. Chedid, M., and S. B. Mizel. 1990. Involvement of cyclic AMP-dependent protein kinases in the signal transduction pathway for interleukin-1. Mol. Cell. Biol. 10:3824-3827.

36. Chedid, M., B. K. Yoza, J. W. Brooks, and S. B. Mizel. 1991. Activation of AP-1 by IL-1 and phorbol esters in T cells: role of protein kinase A and protein phosphatases. J. Immunol. 147:867-873.

37. Rollins, P., S. Witham, K. Ray, N. Thompson, and R. Solari. 1991. Modification of biological responses to interleukin- 1 by agents that perturb signa transduction pathways. Cytokine. 3:42-53.

38. Nishizuka, Y. 1986. Studies and perspectives of protein kinase C. Science (Wash. DC). 233:305-312.

39. Hollingsworth, E. G., D. Ukena, and J. W. Daly. 1986. The protein kinase C activator phorbol-12-myristate-13-acetate enhances cyclic AMP accumulation in pheochromocytoma cells. FEBS (Fed. Eur. Biochem. Soc.) Lett. 196:131-134.

40. Bell, J. D., and L. L. Brunton. 1986. Enhancement of adenylate cyclase activity in S49 lymphoma cells by phorbol esters. J. Biol. Chem. 261:1203612041.

41. Naghshineh, S., M. Noguchi, K.-P. Huang, and C. Londos. 1986. Activation of adipocyte adenylate cyclase by protein kinase C. J. Biol. Chem. 261:14534-14538.

42. Yoshimasa, T., D. R. Sibley, M. Bouvier, R. J. Lef kowitz, and M. G. Caron. 1987. Cross-talk between cellular signalling pathways suggested by phorbol-ester-induced adenylate cyclase phosphorylation. Nature (Lond.). 327:6770.

43. Katada, T., A. G. Gilman, Y. Watanabe, S. Bauer, and K. H. Jakobs 1985. Protein kinase $C$ phosphorylates the inhibitory guanine-nucleotide-binding regulatory component and apparently suppresses its function in hormonal inhibition of adenylate cyclase. Eur. J. Biochem. 151:431-437.

44. Nikula, H., K. Vihko, and I. Huhtaniemi. 1990. Protein kinase $\mathrm{C}$ and Gi-protein mediated modulation of cAMP production in different stages of the rat seminiferous epithelium. Mol. Cell. Endocrinol. 70:247-253.

45. Yatomi, Y., Y. Arata, S. Tada, S. Kume, and M. Ui. 1992. Phosphorylation of the inhibitory guanine-nucleotide-binding protein as a possible mechanism of inhibition by protein kinase $\mathrm{C}$ of agonist-induced $\mathrm{Ca}^{2+}$ mobilization in human platelet. Eur. J. Biochem. 205:1003-1009.

46. Pyne, N. J., M. Freissmuth, and S. Palmer. 1992. Phosphorylation of the spliced variant forms of the recombinant stimulatory guanine-nucleotide-binding regulatory protein $\left(\mathrm{G}_{s \alpha}\right)$ by protein kinase C. Biochem. J. 285:333-338.

47. Grove, J. R., P. J. Deutsch, D. J. Price, J. F. Habener, and J. Avruch. 1989. Plasmids encoding PKI(1-31), a specific inhibitor of cAMP-stimulated gene expression, inhibit the basal transcriptional activity of some but not all cAMP-regulated DNA response elements in JEG-3 cells. J. Biol. Chem. 264:19506-19513.

48. Klausner, R. D. and L. E. Samelson. 1991. T cell antigen receptor activation pathways: the tyrosine kinase connection. Cell. 64:875-878. 